\title{
Correlation of umbilical cord blood haematopoietic stem and progenitor cell levels with birth weight: implications for a prenatal influence on cancer risk
}

\author{
WC Strohsnitter', TM Savarese, ${ }^{2,4}$, HP Low ${ }^{3}$, DP Chelmow', P Lagiou ${ }^{4}$, M Lambe ${ }^{5}$, K Edmiston $^{6}$, Q Liu $^{2}$, I Baik $^{2}$, \\ KL Noller', H-O Adami ${ }^{5,7}$, D Trichopoulos ${ }^{7}$ and C-C Hsieh ${ }^{*, 2,5,7}$ \\ 'Department of Obstetrics and Gynecology, Tufts-New England Medical Center, Boston, MA, USA; ${ }^{2}$ Department of Cancer Biology and Cancer Center, \\ University of Massachusetts Medical School, Worcester, MA, USA; ${ }^{3}$ Department of Neurology, University of Massachusetts Medical School, Worcester, \\ MA, USA; ${ }^{4}$ Department of Hygiene and Epidemiology, School of Medicine, Athens University, Athens, Greece; ${ }^{5}$ Department of Medical Epidemiology and \\ Biostatistics, Karolinska Institutet, Stockholm, Sweden; ${ }^{6}$ Division of Hematology/Oncology, Department of Medicine, UMass Medical School and UMass \\ Memorial Health Care, Worcester, MA, USA; ${ }^{7}$ Department of Epidemiology, Harvard School of Public Health, Boston, MA, USA
}

We examined the relation with birth weight and umbilical cord blood concentrations of haematopoietic stem and progenitor populations in 288 singleton infants. Across the whole range of birth weight, there was a positive relation between birth weight and $\mathrm{CD} 34^{+} \mathrm{CD}^{-} 8^{-}$cells, with each $500 \mathrm{~g}$ increase in birth weight being associated with a $15.5 \%$ higher (95\% confidence interval: I.6$31.3 \%$ ) cell concentration. $\mathrm{CD}_{4}{ }^{+}$and $\mathrm{CD} 4^{+}{ }^{\mathrm{c}-\mathrm{kit}}{ }^{+}$cells had J-shaped relations and CFU-GM cells had a U-shaped relation with birth weight. Among newborns with $\geqslant 3000 \mathrm{~g}$ birth weights, concentrations of these cells increased with birth weight, while those below $3000 \mathrm{~g}$ had higher stem cell concentrations than the reference category of 3000-3499 g. Adjustment for cord blood plasma insulin-like growth factor-I levels weakened the stem and progenitor cell-birth weight associations. The positive associations between birth weight and stem cell measurements for term newborns with a normal-to-high birth weight support the stem cell burden hypothesis of cancer risk.

British Journal of Cancer (2008) 98, 660-663. doi:10.1038/sj.bjc.6604I83 www.bjcancer.com

Published online 5 February 2008

(C) 2008 Cancer Research UK

Keywords: birth weight; cancer risk; prenatal exposure; stem cell

The in utero environment and perinatal factors may influence cancer risk of the offspring later in life (Trichopoulos, 1990). One parameter that reflects in utero/perinatal influences, that is birth weight, has been positively correlated with subsequent risk of childhood cancer (Schüz and Forman, 2007) and, in adults, breast (Michels and Xue, 2006), prostate (Eriksson et al, 2007) and colorectal cancers (Nilsen et al, 2005) and, indeed, overall cancer risk (Ahlgren et al, 2007). Mechanistically, a 'stem cell burden' theory (Adami et al, 1995) has been proposed to account for the positive relationship between birth weight and the risk of certain cancers, especially that of the breast. By this hypothesis, the levels of in utero/perinatal mitogens and other factors determine the size of the stem cell pools in the developing fetus; elevated tissue stem cell numbers drive the formation of larger organs and hence might be associated with larger birth weights. The greater the stem cell

*Correspondence: Dr C-C Hsieh, Division of Biostatistics and Epidemiology, Department of Cancer Biology, UMass Cancer Center, University of Massachusetts Medical School, Worcester, MA, USA;

E-mail: chung.hsieh@umassmed.edu

"Deceased.

Received 29 October 2007; revised 30 November 2007; accepted 7 December 2007; published online 5 February 2008 pool size, however, the greater the chance that one of the stem cells will be mutated by a carcinogen, or undergo a DNA replicative error, initiating oncogenic transformation. Hence, individuals with high birth weights might be at greater lifetime cancer risk (Trichopoulos et al, 2005).

The stem cell burden theory predicts (1) that the in utero levels of particular mitogens should correlate positively with stem cell population levels and (2) that the stem cell levels should correlate positively with birth weight. In a previous study, we demonstrated that the umbilical cord blood concentrations of various haematopoietic stem and progenitor populations correlated with cord blood plasma levels of particular mitogens, especially insulin-like growth factor-1 (IGF-1) (Savarese et al, 2007). Here, we determine whether or not these measurable haematopoietic stem cell/ progenitor values, serving as surrogates of overall stem cell potential, are positively associated with birth weight.

\section{MATERIALS AND METHODS}

The umbilical cord blood study protocol was approved by the institutional review boards of the American Red Cross, the University of Massachusetts Medical School, the University of Massachusetts/Memorial Health Care System, St. Vincent's 
Hospital and Tufts-New England Medical Center (T-NEMC). Consenting study subjects were recruited from one of two sources: (1) participants in the Worcester, MA-based American Red Cross cord blood program (ACBP), in which a haematopoietic stem cells from umbilical cord blood were collected for possible transplantation, from August 2002 to June 2003, and (2) pregnant women delivering at T-NEMC from October 2004 to April 2006. All the cord blood samples were from full-term (gestational age $\geqslant 37$ weeks) singleton infants. The processing of samples, which includes the determination of cord blood volumes, the determination of initial levels of total nucleated cells (TNC) and mononuclear cells (MNC) before centrifugations or manipulation, the quantitation of haematopoietic stem/progenitor cell populations and the determination of cord blood plasma hormone levels, have been described (Savarese et al, 2007). The haematopoietic stem and progenitor populations that were quantitated (1) CD $34^{+}$cells, a heterogeneous population of early multipotent stem and progenitor cells, committed progenitors and differentiating cells (Xiao and Dooley, 2000); (2) $\mathrm{CD} 34^{+} \mathrm{CD} 38^{-}$cells, which represent more primitive stem cells depleted of lineage-committed precursors (Xiao and Dooley, 2000); (3) $\mathrm{CD}_{3}{ }^{+}{ }^{\mathrm{c}-k i t^{+}}$cells, which also represent a more primitive stem cell population that has relatively high cloning efficiencies in semisolid culture (Sharkey et al, 1994; Mayani and Lansdorp, 1998); and (4) granulocytemacrophage colony forming units (CFU-GM), a functional measure of the number of proliferative granulocyte/macrophagecommitted haematopoietic precursor cells (Abboud et al, 1992; Hoffbrand et al, 2001).

Birth weight was first studied as a categorical variable $(<3000$, $3000-3499,3500-3999$ and $\geqslant 4000 \mathrm{~g}$ ). Geometric means for the stem cell measurements were estimated within the indicated categories of birth weight. Multivariate linear regression was used to examine the association between natural log-transformed measures of stem cell potential (dependent variable) and birth weight (independent variable, using 3000-3499 $\mathrm{g}$ as the reference), adjusting for maternal and neonatal characteristics (mother's age, race of parents, number of live births, gestation duration, baby's gender, delivery time and study site). To assess whether there was an underlying linear trend, birth weight was next analyzed as a continuous variable across the whole range of birth weight values with the effect estimates expressed for each $500 \mathrm{~g}$ increase in birth weight. The fitted coefficients from the regression analyses were exponentiated to obtain the estimated proportional change in birth weight associated with each independent variable. Statistical significance was set at 0.05 (two-sided). Levels of IGF-1, which had the strongest association with levels of stem cells among the hormones and growth factors examined in a previous analysis (Savarese et al, 2007), were further adjusted to explore its influence on the association between birth weight and stem cell measurements.

\section{RESULTS}

The characteristics of the study subjects are shown in Table 1. Subjects from the ACBP and T-NEMC patient groups had similar age and gestation duration. Parental ethnicity was more varied in the T-NEMC samples, while the ACBP subjects had higher parities, more male newborns and lower birth weights.

The associations were analysed in multivariate analysis adjusting for maternal age, parental race, parity, gestation duration, gender, delivery time and study site (Table 2, upper panel). There was a J-shaped association between birth weight categories and concentrations of TNC (lymphocytes, monocytes and granulocytes), as well as a J-shaped relation with MNC (lymphocytes and monocytes), both including more differentiated cells. Among the stem cell populations, there was a positive association with $\mathrm{CD} 34^{+} \mathrm{CD}^{-} 8^{-}$cells across the whole range of birth weight categories, with each $500 \mathrm{~g}$ increase being associated with $15.5 \%$
Table I Characteristics of the study subjects by study site

\begin{tabular}{|c|c|c|}
\hline Characteristics & $\begin{array}{c}\text { ACBP }(n=39) \\
\text { Mean } \pm \text { s.d. or } N(\%)\end{array}$ & $\begin{array}{c}\text { T-NEMC }(n=249) \\
\text { Mean } \pm \text { s.d. or } N(\%)\end{array}$ \\
\hline Mother's age (years) & $29.7 \pm 5.1$ & $30.1 \pm 5.6$ \\
\hline \multicolumn{3}{|l|}{ Parity } \\
\hline 1 & $14(35.9)$ & $104(45.0)$ \\
\hline 2 & $12(30.8)$ & $64(27.7)$ \\
\hline 3 & $7(\mid 8.0)$ & $39(16.9)$ \\
\hline 4 or more & $6(15.4)$ & $24(10.4)$ \\
\hline \multicolumn{3}{|c|}{ Race/ethnicity of mother and biological father } \\
\hline Both Caucasian & $36(92.3)$ & | | | (52.4) \\
\hline Both African-American & I (2.6) & $19(9.0)$ \\
\hline Both Asian & $0(0.0)$ & $39(18.4)$ \\
\hline Both Hispanic & $0(0.0)$ & $14(6.6)$ \\
\hline Mixed & $2(5.1)$ & $29(13.7)$ \\
\hline Gestation duration (weeks) & $39.6 \pm 1.4$ & $39.6 \pm 1.2$ \\
\hline \multicolumn{3}{|l|}{ Newborn gender } \\
\hline Male & $21(55.3)$ & $113(50.0)$ \\
\hline Female & $17(44.7)$ & $113(50.0)$ \\
\hline Birth weight (g) & $3313.1 \pm 450.6$ & $3416.4 \pm 428.2$ \\
\hline$<3000$ & || (28.2) & $40(16.1)$ \\
\hline $3000-3499$ & $15(38.5)$ & $110(44.2)$ \\
\hline $3500-3999$ & II (28.2) & $77(30.9)$ \\
\hline$\geqslant 4000$ & $2(5.1)$ & $22(8.8)$ \\
\hline
\end{tabular}

Abbreviations: $\mathrm{ACBP}=$ American Red Cross Cord Blood Program; T-NEMC $=$ Tufts-New England Medical Center. Data on some variables were unavailable for subjects with missing values.

higher levels of this cell population (95\% confidence interval: 1.6, $31.3 \%)$. A J-shaped relation was observed for the $\mathrm{CD}^{+} 4^{+}$and $\mathrm{CD} 4^{+} \mathrm{c}-\mathrm{kit}^{+}$cells: for birth weights of $3000 \mathrm{~g}$ or greater, stem cell concentrations increased with birth weight, while the lowest category of $<3000 \mathrm{~g}$ had higher levels than the category of $3000-$ 3499 g. For CFU-GM, an approximate U-shaped relation was observed, with the lowest birth weight category having the highest levels of this cell population (Table 2, upper panel).

Adjusting for cord blood plasma levels of IGF-1 in the multivariate analysis weakens the association (Table 2, lower panel). The association with $\mathrm{CD} 34^{+} \mathrm{CD} 38^{-}$remained positive but was no longer statistically significant: each $500 \mathrm{~g}$ increase in birth weight was associated with a $7.9 \%$ increase in this cell subpopulation (95\% confidence interval: $-6.2,24.0 \%$ ). The lowest weight category continued to have the highest CFU-GM cells after adjusting for IGF-1 levels.

We conducted further analyses adjusting for other hormones and in samples from different ethnic groups. Adjusting for estriol or insulin-like growth factor binding protein-3, which had statistically significant but weaker associations with cord blood levels of stem cells (Savarese et al, 2007), in place of IGF-1, had much less effect on the association with birth weight (data not shown). A linear relation between stem cell measurements and birth weight was observed for newborns whose parents were Caucasian, but did not have a consistent shape among samples in the mixed non-Caucasian group (Table 3).

\section{DISCUSSION}

The stem cell burden hypothesis has been invoked as an explanation for the positive link between birth weight and risk for both childhood and adult cancers (Adami et al, 1995). This hypothesis proposes that in utero environments that promote 
Table 2 Multiple linear regression analysis for the association between measurements of haematopoietic stem cell populations and birth weight

\begin{tabular}{|c|c|c|c|c|c|c|}
\hline Analytic model & $\begin{array}{l}\text { Cell } \\
\text { measurements }\end{array}$ & \multicolumn{4}{|c|}{ Birth weight $(\mathrm{g})$ in categories } & $\begin{array}{l}\text { Birth weight per } \\
500 \mathrm{~g} \\
\\
\text { \% Difference } \\
\text { (95\% Cl) }\end{array}$ \\
\hline $\begin{array}{l}\text { Adjusted for core } \\
\text { covariates }^{\mathrm{b}}\end{array}$ & 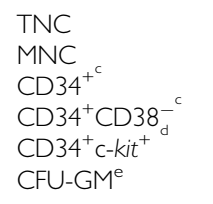 & $\begin{aligned} & 2.1(-8.5,14.0) \\
& 5.7(-6.4,19.3) \\
& 2.4(-19.2,29.7) \\
&-1.1(-23.6,28.1) \\
& 13.7(-14.0,50.4) \\
& \mathbf{3 7 . 0}(\mathbf{2 . 1}, \mathbf{8 3 . 8})\end{aligned}$ & $\begin{array}{l}0.0(\mid 15.00) \\
0.0(6.9 \mid) \\
0.0(7.04) \\
0.0(3.1 \mid) \\
0.0(5.80) \\
0.0(4.04)\end{array}$ & $\begin{array}{r}7.8(-1.7,18.3) \\
6.5(-3.9,18.0) \\
12.5(-8.1,37.7) \\
19.1(-4.3,48.1) \\
18.9(-5.5,49.6) \\
29.0(-0.1,66.6)\end{array}$ & $\begin{array}{c}8.4(-8.1,27.8) \\
12.5(-6.2,34.9) \\
20.8(-15.5,72.8) \\
\mathbf{4 7 . 9}(\mathbf{0 . 4}, \mathbf{I} \mathbf{1 7 . 8}) \\
34.2(-10.4, \mid 101.1) \\
31.4(-|6.2,| 06.1)\end{array}$ & $\begin{array}{r}3.0(-2.5,8.9) \\
2.1(-3.9,8.4) \\
9.5(-2.6,23.2) \\
\mathbf{1 5 . 5}(\mathbf{I . 6 , 3 1 . 3 )} \\
10.0(-4.0,26.1) \\
6.1(-8.4,23.0)\end{array}$ \\
\hline $\begin{array}{l}\text { Adjusted for core } \\
\text { covariates and IGF-I }\end{array}$ & $\begin{array}{l}\text { TNC } \\
\text { MNC } \\
\mathrm{CD} 34^{+^{c}} \\
\text { CD34 } \\
\text { CD34 } 34^{+} \mathrm{C}-\mathrm{kit}^{+{ }^{+}} \\
\text {CFU-GM }\end{array}$ & $\begin{aligned} 0.6 & (-10.0,12.5) \\
4.0 & (-8.0,17.7) \\
11.0 & (-12.3,40.6) \\
5.2 & (-19.0,36.6) \\
22.8 & (-6.9,62.1) \\
\mathbf{4 5 . 6} & (\mathbf{8 . 6}, \mathbf{9 5 . 1})\end{aligned}$ & $\begin{array}{l}0.0(\mid 15.00) \\
0.0(6.9 \mid) \\
0.0(7.04) \\
0.0(3.11) \\
0.0(5.80) \\
0.0(4.04)\end{array}$ & $\begin{array}{r}9.7(-0.4,20.8) \\
8.5(-2.5,20.6) \\
2.5(-16.5,25.8) \\
10.9(-11.5,38.8) \\
7.0(-15.3,35.2) \\
15.5(-11.6,50.9)\end{array}$ & $\begin{array}{c}12.3(-5.5,33.4) \\
16.8(-3.5,41.4) \\
-0.3(-31.0,44.0) \\
27.6(-14.7,90.9) \\
10.5(-26.9,66.9) \\
11.5(-29.8,77.1)\end{array}$ & $\begin{array}{r}4.5(-1.5,11.0) \\
3.7(-2.9,10.8) \\
0.6(-11.4,14.2) \\
7.9(-6.2,24.0) \\
0.7(-12.9,16.4) \\
-1.7(-16.2,15.3)\end{array}$ \\
\hline
\end{tabular}

a Unadjusted geometric means. TNC, initial total nucleated cells $\times 10^{6}$ per $\mathrm{ml}$; MNC, initial mononuclear cells $\times 10^{6}$ per ml; the unit for the stem cell populations $\left(C D 34^{+}\right.$ $\mathrm{CD} 34^{+} \mathrm{CD} 38^{-}, \mathrm{CD} 34^{+} \mathrm{C}-\mathrm{Kit}^{+}$, and CFU-GM) was per $1000 \mathrm{MNC}$. ${ }^{\circ}$ Core covariates included mother's age, race of parents (both Caucasian or not), parity, gestation duration, gender of baby (male or female), delivery time (night or day) and study site (ACBP or T-NEMC). ${ }^{c} n=233$ with complete information on all the covariates. ${ }^{d}$ Determined only in the T-NEMC-derived samples. 'Data from the T-NEMC-derived samples on which this assay was conducted. Statistical significance of P<0.05 are given in bold.

Table 3 Ethnic-specific, core covariate-adjusted ${ }^{a}$ multiple linear regression analysis for the association between measurements of haematopoietic stem cell populations and birth weight

\begin{tabular}{|c|c|c|c|c|c|c|}
\hline \multirow[b]{2}{*}{ Ethnicity } & \multirow[b]{2}{*}{$\begin{array}{l}\text { Stem cell } \\
\text { measurements }\end{array}$} & \multicolumn{4}{|c|}{ Birth weight $(\mathrm{g})$ in categories } & \multirow{2}{*}{$\begin{array}{l}\text { Birth weight per } \\
500 \mathrm{~g} \\
\text { \% Difference } \\
(95 \% \mathrm{Cl})\end{array}$} \\
\hline & & $\begin{array}{c}<3000 \% \\
\text { Difference } \\
\text { (95\% Cl) }\end{array}$ & $\begin{array}{c}3000-3499 \\
\text { Reference } \\
\text { (geometric } \\
\text { mean }^{\text {b) }}\end{array}$ & $\begin{array}{c}3500-3999 \% \\
\text { Difference } \\
\text { (95\% Cl) }\end{array}$ & $\begin{array}{c}\geqslant 4000 \% \\
\text { Difference } \\
(95 \% \mathrm{Cl})\end{array}$ & \\
\hline $\begin{array}{l}\text { Both parents } \\
\text { Caucasian }\end{array}$ & $\begin{array}{l}\mathrm{CD} 34^{+} \\
\mathrm{CD}^{+} 4^{+} \mathrm{CD} 38^{-} \\
\mathrm{CD} 34^{+} \mathrm{c}-\mathrm{kit}^{+} \\
\text {CFU-GM }\end{array}$ & $\begin{array}{r}-13.9(-37.2,18.0) \\
-18.0(-43.0,17.9) \\
-11.5(-40.8,32.3) \\
19.3(-25.9,92.8)\end{array}$ & $\begin{array}{l}0.0(7.73) \\
0.0(3.4 I) \\
0.0(6.44) \\
0.0(4.0 I)\end{array}$ & $\begin{array}{l}8.3(-15.2,38.3) \\
14.3(-13.7,51.4) \\
18.4(-11.0,57.5) \\
36.9(-3.4,94.1)\end{array}$ & $\begin{array}{c}37.5(-|1.2,1| 3.1) \\
\mathbf{8 0 . 5}(\mathbf{9 . 1}, \mathbf{1 9 8 . 7}) \\
63.4(-1.0,169.5) \\
40.0(-25.3,162.5)\end{array}$ & $\begin{array}{l}16.6(0.9,34.7) \\
23.8(4.7,46.4) \\
22.9(3.6,45.8) \\
19.7(-3.3,48.2)\end{array}$ \\
\hline $\begin{array}{l}\text { Either parent non- } \\
\text { Caucasian }\end{array}$ & $\begin{array}{l}\mathrm{CD} 34^{+} \\
\mathrm{CD}^{+} 4^{+} \mathrm{CD} 38^{-} \\
\text {CD } 34^{+} \mathrm{c}-\mathrm{kit}^{+} \\
\text {CFU-GM }\end{array}$ & $\begin{array}{c}28.4(-12.1,87.6) \\
23.2(-16.2,81.2) \\
42.1(-6.2, \mid 15.5) \\
\mathbf{6 8 . 4}(\mathbf{I 4 . 0 ,} \mathbf{1 4 8 . 6 )}\end{array}$ & $\begin{array}{l}0.0(6.47) \\
0.0(2.84) \\
0.0(5.39) \\
0.0(4.08)\end{array}$ & $\begin{array}{l}19.9(-16.6,72.3) \\
28.2(-10.8,84.4) \\
22.2(-17.2,80.4) \\
21.0(-18.1,78.6)\end{array}$ & $\begin{array}{r}-0.6(-46.6,85.3) \\
13.5(-39.1, \quad 1 \mid 1.7) \\
9.2(-43.9, \quad 112.6) \\
24.3(-37.5, \quad 147.1)\end{array}$ & $\begin{array}{r}0.5(-18.1,23.5) \\
6.3(-13.8,31.0) \\
-0.4(-20.4,24.7) \\
-7.3(-26.0,16.1)\end{array}$ \\
\hline
\end{tabular}

${ }^{a}$ Core covariates included mother's age, parity, gestation duration, gender of baby (male or female), delivery time (night or day) and study site (ACBP or T-NEMC). ${ }^{\text {Unadjusted }}$ geometric means. The unit for the stem cell measurements was per 1000 MNC. Statistical significance of $\mathrm{P}<0.05$ are given in bold.

expansion of stem cell pools result in infants with high birth weights; the larger the stem cell pool, the greater the risk that one of these stem cells will undergo malignant transformation. In support of the first tenet of this hypothesis, we have demonstrated that the concentrations of stem and progenitor cell populations in umbilical cord blood, serving as surrogates for overall stem cell potential, correlate with cord blood plasma levels of certain mitogens, notably IGF-1 (Savarese et al, 2007). The hypothesis also predicts that newborns with high birth weights should have elevated stem cell populations. Our findings indicate that there is a positive association between birth weight and haematopoietic stem cell measurements in the cord blood samples among newborns with normal-to-high $(\geqslant 3000 \mathrm{~g})$ birth weights. This association is strongest with $\mathrm{CD} 34^{+} \mathrm{CD} 38^{-}$cells, a relatively primitive haematopoietic stem cell population. These data are in line with previous studies, which showed a positive relationship between cord blood $\mathrm{CD}^{+}{ }^{+}$or CFU-GM levels and birth weight (Shlebak et al, 1998; Ballen et al, 2001; Aroviita et al, 2004).

However, in our study, newborns in the lowest birth weight category $(<3000 \mathrm{~g})$ can have higher levels of stem/progenitor cell measurements than those with $3000-3499 \mathrm{~g}$ birth weight resulting in a J- or U-shaped relation between stem cell levels and birth weight. This finding is intriguing, as J- or U-shaped relationships have often been observed in childhood cancers (Schüz and Forman, 2007) and neurological (Schüz et al, 2001; Von Behren and Reynolds, 2003), prostate (Eriksson et al, 2007), colorectal (Nilsen et al, 2005) and early-onset breast cancers (Sanderson et al, 1996; Innes et al, 2000; Mellemkjaer et al, 2003).

The possible elevated levels of stem cells at low birth weight warrant further investigations. Using birth weight to define smallfor-gestation for full-term healthy infants, a majority (>86\%) of such infants undergo accelerated growth during the first 6-12 months after birth and attain normal height later in life (Karlberg and Albertsson-Wikland, 1995). Premature infants (i.e., those born before the 33rd gestational week, generally with low birth weights) have been shown to have elevated foetal and cord blood CD $34^{+}$ and $\mathrm{CD} 34^{+} \mathrm{CD} 38^{-}$levels relative to full-term infants (most with a normal birth weight) (Shields and Andrews, 1998; Wyrsch et al, 1999). Relevant to this phenomenon, it has been reported that premature female newborns have an increased risk for breast cancer later in life (Ekbom et al, 2000). It is not known whether premature or small newborns harbour elevated stem/progenitor 
cell populations, because these populations have not had enough developmental time to undergo a normal course of differentiation, or if such infants build up a stem cell reserve for growth compensation during the postnatal period. In any case, our J-shaped relation observed between birth weight and stem cell measurements requires further confirmation as ethnicity-specific results showed a linear relation in the considerably larger group of Caucasian cord blood samples.

Finally, we examined cord blood plasma IGF-1 levels in relation to stem cell levels and birth weight. Insulin-like growth factor-1 had a positive association with stem cell measurements in our samples (Savarese et al, 2007) and was strongly associated with birth weight (geometric means were 41.18, 57.86, 78.45 and $102.77 \mathrm{ng} \mathrm{ml}^{-1}$, respectively, for the four categories of birth weight in Table 2 and in the literature (Bennett et al, 1983; Fant et al, 1993; Reece et al, 1994)). The growth hormone/IGF-1 axis has been suggested to serve as a master developmental regulator, coordinating stem cells in multiple organs (Ginestier and Wicha, 2007). When we controlled for cord plasma IGF-1 levels, the associations were considerably weakened. This would be expected if IGF-1 regulates stem cell potential and this is, in turn, a determinant of birth weight. To determine whether birth weight is an accurate reflection of stem cell potential, the focus should be on the results without adjusting for IGF-1.

\section{REFERENCES}

Abboud M, Xu F, LaVia M, Laver J (1992) Study of early hematopoietic precursors in human cord blood. Exp Hematol 20: 1043-1047

Adami H-O, Persson I, Ekbom A, Wolk A, Ponten J, Trichopoulos D (1995) The aetiology and pathogenesis of human breast cancer. Mutat Res 333: 29-35

Ahlgren M, Wohlfahrt J, Olsen LW, Sørensen TIA, Melbye M (2007) Birth weight and risk of cancer. Cancer 110: $412-419$

Aroviita P, Teramo K, Hiilesmaa V, Westman P, Kekomaki R (2004) Birthweight of full-term infants is associated with cord blood CD34+ cell concentration. Acta Paediatr 93: 1323-1329

Ballen KK, Wilson M, Wuu J, Ceredona AM, Hsieh C, Stewart FM, Popovsky MA, Quesenberry PJ (2001) Bigger is better: maternal and neonatal predictors of hematopoietic potential of umbilical cord blood units. Bone Marrow Transplant 27: 7-14

Bennett A, Wilson DM, Liu F, Nagashima R, Rosenfeld RG, Hintz RL (1983) Levels of insulin-like growth factors I and II in human cord blood. J Clin Endocrinol Metab 57: 609-612

Ekbom A, Erlandsson G, Hsieh CC, Trichopoulos D, Adami H-O, Cnattingius S (2000) Risk of breast cancer in prematurely born women. J Natl Cancer Inst 92: 840-841

Eriksson M, Wedel H, Wallander M-A, Krakau I, Hugosson J, Carlsson S, Svärdsudd K (2007) The impact of birth weight on prostate cancer incidence and mortality in a population-based study of men born in 1913 and followed up from 50 to 85 years of age. The Prostate 67: 1247-1254

Fant M, Salafia C, Baxter RC, Schwander J, Vogel C, Pezzullo J, Moya F (1993) Circulating levels of IGFs and IGF binding proteins in human cord serum: relationships to intrauterine growth. Regul Pept 48: 29-39

Ginestier C, Wicha MS (2007) Mammary stem cell number as a determinate of breast cancer risk. Breast Cancer Res 9: 109

Hoffbrand AV, Pettit JE, Moss P (2001) Essential Haematology 4th edn, pp 1 -11. Malden, MA: Blackwell Science

Innes K, Byers T, Schymura M (2000) Birth characteristics and subsequent risk for breast cancer in very young women. Am J Epidemiol 152: 1121-1128

Karlberg J, Albertsson-Wikland K (1995) Growth in full-term small-forgestational-age infants: from birth to final height. Pediatr Res 38: 733-739

Mayani H, Lansdorp PM (1998) Biology of human umbilical cord bloodderived hematopoietic stem/progenitor cells. Stem Cells 16: 153-165

Mellemkjaer L, Olsen ML, Sorensen HT, Thulstrup AAM, Olsen J, Olson JH (2003) Birth weight and risk of early-onset breast cancer (Denmark). Cancer Causes Control 14: 61-64

Michels KB, Xue F (2006) Role of birth weight in the etiology of breast cancer. Int J Cancer 119: 2007-2025

Nilsen TIL, Romundstad PR, Troisi R, Potischman N, Vatten LJ (2005) Birth size and colorectal cancer risk: a prospective population based study. Gut 54: $1728-1732$
We conclude that there is a J- or U-shaped positive association between birth weight and stem cell measurements, linear among term newborns with normal-to-high birth weight and stronger with the more primitive stem cell sub-population. The nonlinear relationship, however, suggests that birth weight is not an unequivocal indicator of stem cell potential in the context of a prenatal origin of cancer risk. Quantitation of stem cell pools might prove to be a more accurate predictor of cancer risk than birth weight per se, in accordance with the stem cell burden hypothesis.

\section{ACKNOWLEDGEMENTS}

We are grateful for the effort of the attending physicians and residents of the Department of Obstetrics and Gynecology and Family Practice and the staff on the Labor and Delivery ward at the Tufts-New England Medical Center. This study was support by a Grant (R01CA90902) from the US National Institutes of Health. PL, HOA, DT and CCH were supported in part by the W81XWH-05-10314 Innovator Award, USA. Department of Defense Breast Cancer Research Program, Office of the Congressionally Directed Medical Research Programs.

Reece EA, Wiznitzer A, Le E, Homko CJ, Behrman H, Spencer EM (1994) The relation between human fetal growth and fetal blood levels of insulin-like growth factors I and II, their binding proteins and receptors. Obstet Gynecol 84: 88-95

Sanderson M, Williams MA, Malone KE, Stanford JL, Emanuel I, White E, Daling JR (1996) Perinatal factors and risk of breast cancer. Epidemiology 7: $34-37$

Savarese TM, Strohsnitter WC, Low HP, Liu Q, Baik I, Okulicz W, Chelmow DP, Lagiou P, Quesenberry PJ, Noller KL, Hsieh CC (2007) Correlation of umbilical cord blood hormones and growth factors with stem cell potential: implications for the prenatal origin of breast cancer hypothesis. Breast Cancer Res 9: R29

Schüz J, Forman MR (2007) Birthweight by gestational age and childhood cancer. Cancer Causes Control 18: 655-663

Schüz J, Kaletsch U, Meinert R, Kaatsch P, Spix C, Michaelis J (2001) Risk factors for neuroblastoma at different stages of disease Results from a population-based case-control study in Germany. J Clin Epidemiol 54: $702-709$

Sharkey AM, Jokhi PP, King A, Loke YW, Brown KD, Smith SK (1994) Expression of c-kit and kit ligand at the human maternofetal interface. Cytokine 6: $195-205$

Shields LE, Andrews RG (1998) Gestational age changes in circulating CD34+ hematopoietic stem/progenitor cells in fetal cord blood. Am J Obstet Gynecol 178: 931 - 937

Shlebak AA, Roberts IAG, Stevens TA, Syzdlo RM, Goldman JM, Gordon MY (1998) The impact of antenatal and perinatal variables on cord blood haemopoietic stem/progenitor cell yield available for transplantation. Br J Haematol 103: 1167 - 1171

Trichopoulos D (1990) Does breast cancer originate in utero? Lancet 335: 939-940

Trichopoulos D, Lagiou P, Adami HO (2005) Towards an integrated model for breast cancer etiology: the crucial role of the number of mammary tissue-specific stem cells. Breast Cancer Res 7: $13-17$

Von Behren J, Reynolds P (2003) Birth characteristics and brain cancers in young children. Int J Epidemiol 32: 248-256

Wyrsch A, dale Carbonare V, Jansen W, Chklovskaia E, Nissen C, Surbek D, Holzgreve W, Tichelli A, Wodnar-Filipowicz A (1999) Umbilical cord blood from preterm human fetuses is rich in committed and primitive hematopoietic progenitors with high proliferative and self-renewal capacity. Exp Hematol 27: 1338-1345

Xiao M, Dooley DC (2000) Cellular and molecular aspects of human $\mathrm{CD} 34^{+} \mathrm{CD} 38^{-}$precursors: analysis of a primitive hematopoietic population. Leuk Lymphoma 38: 489-497 